\title{
Filippo Marotta Rizzo, Lu scavittu e altre novelle, with prefaces by Titta Scidà and Carlo Marullo di Condojanni (Catania: Maimone, 2004), pp. 79
}

\author{
by Francesco Milazzo
}

The tales narrated in Lu scavittu e altre novelle [The (marble) digger and other novels] are a token of grand-filial love by the author. They take place in the land of his forefathers, i.e. the Sicilian valleys descending from the Nebrodi mountain range to the Tyrrhenian Sea, and they are set in the late days of the Borbonic crown, i.e. before Garibaldis expedition brought the eight-century-old southern-Italian kingdom to a sudden end. References to more recent times can be found only in the twelfth chapter--the last chapter in the book--as the author evokes some personal experiences from the 1960 .

The valleys depicted in Filippo Marotta Rizzos book cover a small geographical area, already inhabited in ancient times by Siculians, Greeks and Romans. This area is in many ways both close to and far from well-known Sicilian places of major importancehistorically, economically, demographically--such as Messina, the slightly more distant cities of Palermo and Trapani, and the islands deep south, 20okm closer to Africa.

The reader should recall that Sicily is the biggest island in the Mediterranean Sea and it has often been referred to as a sub-continent comprising many and utterly diverse geographical and human realities. This diversity is perceived most profoundly by the local inhabitants, contrarily to the external observer or foreign visitor, who may have, even justifiably, a rather monolithic notion of what Sicily is like. Marotta Rizzos book explores one of the many faces, indeed a very specific one, of the island. This fact perhaps explains the books success amongst his fellow-Sicilians, as it has been reprinted three times, and the limited knowledge of it outside Sicily.

Filippo Marotta Rizzo was born in 1947 and holds a degree in Modern Literature awarded in 1971 by the University of Catania. Until 1998 and for many years, he worked for the Bank of Sicily, yet never deserting his prior interests in literary studies, historical research, and first-hand composition. In the 1960s, he was active politically as vice-secretary of Italys Monarchic Front Youth, aiming at restoring the monarchic form of government, which had been abolished after the end of the Second World War. As such, Marotta Rizzo could be seen as a laudator temporis acti, filled with nostalgia and thoroughly skeptical about modern events, lifestyles and political ideas. However, such an interpretation would be simplistic, if not blatantly erroneous. Marotta Rizzo has indeed strong opinions and ideals to which he is committed, but he avoids turning his own literary creations into propaganda. 
Besides, he does pine for the good old times, but not because they are old, rather because they were good.

Amongst the constant elements of the tales presented in this slender book shine the Sicilians good dispositionstheir actual good dispositions, not the Jesuitical ones. The book offers several examples to ponder upon: dr. Liottas admirable tenderness towards Bettina (7th chapter); the most powerful religious fervour pervading the Verga-esque (as insightfully detected by Don Carlo Marullo di Condojanni), heartbreaking tale of Mara and her family (8th chapter); Donna Maranicas and Don Filippos goodness and magnanimity as tokens of Gods own Providence (8th chapter); Colas Christian solidarity, which is opposed to the abstract fraternité of the French Revolution (10th chapter); Don Giuseppes clemency, coloured by the feeble pale light of a winter sunray, yet a wish for better times (10th chapter): charitys light.

Further elements could be discussed, since this unpretentious book turns its friendly simplicity of domestic storytelling into a trumping card. Marotta Rizzos apparently ordinary stories are rooted in official history, of which they reveal interesting and vivid aspects by way of common events occurring in peripheral valleys of the Sicilian sub-continent. These beautiful valleys, though peripheral, did not lack cultural vigour, as exemplified by DeMaistre scholar Biagio Rizzo (2nd chapter) and the poet Lucio Piccolo (12th chapter).

Also, Marotta Rizzo shows how sincere and life-shaping faith and religion can be. Even if not devoid of nearly grotesque and vehemently class-conscious aspectsviz. the assault inside a Church by the noblewoman Donna Mira onto new money Sarina (3rd and $\mathrm{cf} .5^{\text {th }}$ chapter)faith and religion bring hope to a people naturally prone to pessimism.

Moreover, the author succeeds in representing acutely the classical theme of the relationship between different generations (4th and 9th chapter), as well as the unexpected and rather modern realism of the clergy, whereby a mother superior deals with an infatuated novice by asserting that it is better to be a good wife than a bad nun (4th chapter). Not to mention a typically Sicilian, once again Verga-esque theme, i.e. la roba (literally meaning stuff or things, but it suggests the almost compulsive drive to greedily accumulate material wealth, as personified by Giovanni Vergas larger-than-life Mastro Don Gesualdo; $5^{\text {th }}$ and 9th chapter).

Marotta Rizzos book deserves praise for its substantial levitasthe oxymoron is intended. Lu scavittu makes for a truly pleasant read, probably the outcome of the authors own pleasure in writing it. Clearly, Marotta Rizzo indulged in the verily human, personal desire to be engulfed by the memories of anothers memoriesLife is memory, as Singer wrote. Still, via the creative reconstruction of partial popular reminiscences and actual archival documentation, for which he is commended by the former president of the Youth Court of Catania dr. Scid, Marotta Rizzo achieves the twofold goal of providing a piece of historical research and a literary work. From it, as Sicilian novelist and poet Gesualdo Bufalino would state (cf. Museo dombre), 
emanates the residual warmth of past existences, the furtive footsteps of minor history, which is typically the most instructive.

(English translation by Giorgio Baruchello)

FRANCESCO MILAZZO: Born in 1955. Full Professor of Roman Law at the Law Faculty of Catania University. Member of the Editorial Staff of IURA. International Survey of Roman and Ancient Law, founded in 1950, and of many historical-juridical Societies in Italy and abroad. Grantee at the Albert-Ludwigs-Universitaet of Freiburg i. Br., where he was later appointed "wissenschaftlicher Assistent". His books and articles are concerned with different aspects of Roman public and private law such as the succession of the Roman emperors, private law contracts of the Roman state, oath and obedience to the statutes. He has given papers and lectures in Spain, Poland, Germany, France, Austria and several Italian Universities. 